\title{
IMPLEMENTATION OF MODEL-ELICITING ACTIVITIES TO IMPROVE THE ABILITY OF MATHEMATICAL PROBLEM SOLVING
}

\author{
Rubaitun $^{1}$, Ruseffendi ${ }^{2}$, Mumun Syaban ${ }^{3}$ \\ ${ }^{1,2,3}$ IKIP Siliwangi, Cimahi \\ ${ }^{1}$ rubaitun@yahoo.co.id, ${ }^{3}$ mumunsyaban58@gmail.com \\ Received: Jul 16 ${ }^{\text {th }}, 2018$; Accepted: Sep $28^{\text {th }}, 2018$
}

\begin{abstract}
This study aims to determine whether the improvement of students' mathematical problem solving skills that get the learning of Model-Eliciting Activities is better than students who get regular learning. Method in this research is experiment and research design pretest and postest in experiment and control class. The population in this study were all students of MTs Kota Cimahi. School samples were taken at random, and obtained by MTs Negeri Kota Cimahi. Then the sample is selected two class VIII at random class. The experimental class uses Model-Eliciting Activities, while the control class uses ordinary learning. The hypothesis in this research is the improvement of student solving abilities of MTs students in Cimahi whose learning using Model-Eliciting Activities is better than using ordinary learning. Research data obtained through the instrument of posttest mathematical problem solving ability. The posttest data is processed by normality test, homogeneity test, and two average difference test using SPSS (Statistical Product and Service Solution) software version 16.0 for Windows. The results showed that the improvement of problem solving ability of MTs students in Cimahi whose learning using Model-Eliciting Activities was better than those using ordinary learning.
\end{abstract}

Keywords: Model-Eliciting Activities, Mathematical Problem Solving Abilities

\begin{abstract}
Abstrak
Penelitian ini bertujuan untuk mengetahui apakah peningkatan kemampuan pemecahan masalah matematik siswa yang mendapatkan pemebelajaran Model-Eliciting Activities lebih baik daripada siswa yang mendapatkan pembelajaran biasa. Metode pada penelitian ini adalah eksperimen dan desain penelitian pretes dan postes pada kelas eksperimen dan kontrol. Populasi dalam penelitian ini adalah seluruh siswa MTs Kota Cimahi. Sampel sekolah diambil secara acak, dan diperoleh MTs Negeri Kota Cimahi. Kemudian sampel dipilih dua kelas VIII secara acak kelas. Kelas eksperimen menggunakan Model-Eliciting Activities, sedangkan kelas kontrol menggunakan pembelajaran biasa. Hipotesis dalam penelitian ini adalah peningkatan kemampuan pemecahan nasalah siswa MTs di Cimahi yang pembelajarannya menggunakan Model-Eliciting Activities lebih baik daripada yang menggunakan pembelajaran biasa. Data penelitian diperoleh melalui instrumen berupa postest kemampuan pemecahan masalah matematik. Data postest diolah melalui uji normalitas, uji homogenitas, dan uji perbedaan dua rata-rata menggunakan software SPSS (Statistical Product and Service Solution) versi 16.0 for Windows. Hasil penelitian menunjukkan bahwa peningkatan kemampuan pemecahan masalah siswa MTs di Cimahi yang pembelajarannya menggunakan ModelEliciting Activities lebih baik daripada yang menggunakan pembelajaran biasa
\end{abstract}

Kata kunci: Model-Eliciting Activities, Kemampuan Pemecahan Masalah Matematik.

How to Cite: Rubaitun, Ruseffendi, H.E.T., \& Syaban, M. (2018). Implementasi of ModelEliciting Activities to Improve the Ability of Mathematical Problem Solving. JIML, 1 (3), 312317. 


\section{INTRODUCTION}

Problem is something to be solved. Solving problems requires the ability to think and skill. The ability to think and skill in solving problems must be owned by everyone to be able to solve every problem well, because no one never met the problem. Therefore one of the objectives of mathematics learning that is listed in the school curriculum is that students have the ability to solve problems. The ability to solve problems is of course very important in everyday life in general and in particular mathematics lessons. Ability to solve problems is a basic ability in learning mathematics, and is a common goal in learning mathematics. The ability to solve problems is a general goal of teaching mathematics, this means that mathematics can help in solving problems, both in other subjects and in everyday life. The ability to solve the problem prioritizes the process and strategy that is done in solving it rather than the outcome. The skills of the process and strategy become the basic skills in learning mathematics. In everyday learning also found many students can not solve the problem, especially problem-solving problems. On average in each class the number of students who can solve math problems, less than a quarter, sometimes only one or two students per class. This is based on the experience of researchers during the math teacher MTs in Cimahi. Mathematics learning in MTs generally uses a direct learning model, although it has been using the Curriculum 2013. The scientific approach in the 2013 curriculum is still influenced by direct learning model that was previously done. This is because the application of a scientific approach takes a long time for students to understand mathematical concepts. The steps used in the 2013 curriculum course are 5M. Although many forms of approaches and models of learning that can be applied by teachers in teaching and learning activities, but the selection of approaches and models appropriate in addition to organize students in the classroom, can also provide motivation and can develop intellectual ability optimally. Thus the students not only absorb information from teachers, but can play an active role to develop their knowledge independently with the guidance and direction of teachers. One approach that can develop students' intellectual ability optimally is Model-Eliciting Activities. The ModelEliciting Activities (MEAs) approach is a learning approach for understanding, explaining and communicating the concepts contained in a dish through a mathematical modeling process(Permana, 2010). Explains that the MEAs learning is based on the students' real-life situation, working in small groups, and presenting a mathematical model as a solution.(Widyastuti, 2010).The principle of reality in Model-Eliciting Activities enables students to improve problem-solving abilities, because they are perceived and visible in real life. As we know that in real life every person must have faced problems, although with different problems. Problem solving ability requires students to make models in solving problems. And making the model to solve the problem is the main goal in learning ModelEliciting Activities(Chamberlin \& Moon, 2005)

\section{Model-Eliciting Activities}

Model-Eliciting Activities (MEAs) is one of the learning approaches made by math teachers, professors and American and Australian graduates for use by math teachers(Chamberlin \& Moon, 2005). The MEAs approach was developed in mathematics lessons by Less and Doerr (Martadipura, 2012). MEAs were developed in 2003 to meet the needs of math teachers in improving the curriculum at the time. In the beginning MEAs were made for high school students, but in its development MEAs were used also for elementary schools and even colleges (Chamberlin \& Moon, 2005). Model-Eliciting Activities (MEAs) are formed from three words: model, eliciting and activities. Models in Indonesian are defined as models. The meaning of the word model in the Big Indonesian Dictionary is a pattern of something to be created or produced. Eliciting comes from the word elicit which means to bring, gain, obtain, 
314 Rubaitun, Ruseffendi, \& Syaban Implementasi of Model Eliciting Activities to Improve the Ability of Mathematical Problem Solving

create or bring up. Activities in the Indonesian language defined by the activity or activity. So it can be interpreted that Model-Eliciting Activities is an activity or activity to obtain or create a model. Model-Eliciting Activities are activities or activities of students to create or create a model and proceed with testing the model that has been made. Meanwhile Permana said that the approach of Model-Eliciting Activities (MEAs) is a useful learning approach for students to understand, explain and communicate the concepts contained in a dish through the process of mathematical modeling(Permana, 2010). Model-Eliciting Activities (MEAs) have the potential to help students learn deeper and deeper, then retain what they have learned, and continue to utilize their learning outcomes into other problem contexts.

\section{Mathematical Problem Solving Abilities}

Problem is something to be solved. Solving problems requires the ability to think and skill. The ability to think and skill in solving problems must be owned by everyone to be able to solve every problem well, because no one never met the problem. Therefore one of the objectives of mathematics learning that is listed in the school curriculum is that students have the ability to solve problems. Problem solving as disclosed by Branca (Hendriana, Rohaeti, \& Sumarmo, 2017)contains three meanings, namely problem-solving as objectives, problemsolving as a process and problem-solving as a skill. Problem solving as an objective is more to the reason why the problem solving is taught and how to solve math problems. While as a process, more to the student's activities in solving the problem. The third sense as a skill is general skills for students to complete school evaluation and minimum skills that can be used in everyday life. To get the problem-solving skills well everyone should experience the problem-solving process often.

\section{METHOD}

The This research method is experiment where researcher take two class as sample of research, first class gets learning by using Model-Eliciting Activities while second class gets ordinary learning. Before and after learning the two classes got pretest and postes parallel to test problem solving of mathematics.

The design of his research as follows:

A O X O

\section{$\mathrm{AO} \mathrm{O}$}

(Russeffendi, 2005)

Information:

O: instrument questions for pretest $=$ instruments about postes mathematical problem solving of mathematical

$\mathrm{X}$ : Learning by Model-Eliciting Activities

A: Classroom random sampling

The population in this study were all MTs students in Cimahi. School samples were randomly selected and obtained by MTs Negeri Cimahi. The class sample is taken from class VIII. From class VIII of 10 classes, two groups were taken randomly. So that obtained by research sample that is student of class VIII MTs Negeri Cimahi as much as two class where one as experiment class and one class as control class. The data generated from this study in the form of quantitative data and data processing is done with the help of software SPSS (Statistical Product and Service Solution) version 16.0 forWindows.

\section{RESULTS AND DISCUSSION}

\section{Results}

The results of the study and discussion in this chapter are the results of field studies aimed at 
obtaining data by test techniques. The test is performed before after different learning is done between the experimental class and the control class. The experimental class is given the MEAs lesson while the control class still uses regular learning. The variable studied is the ability of mathematical problem solving of MTs students. The material taken in this research is the material of Building Room of Flat Side of VIII class 2nd semester material. The reason for the selection of materials is adjusted to the principles of learning of MEAs and the mathematical syllabus of the revised 2013 curriculum. The research was conducted at MTs Negeri Kota Cimahi based on random selection of MTs se Kota Cimahi. Class VIII which is used as research sample is also taken by random class from 10 classes and obtained class VIII A used as experiment class and class VIII C serve as control class with initial assumption of both classes come from same variance. Class VIIIA amounted to 36 students and VIIIC class numbered 37 students. This research activity was conducted on March 20, 2018 until April 11, 2018.The following is descriptive statistical data for pretest and postes mathematical problem solving abilities for experimental and control classes.

Tabel 1. Pretest and PostestStatistics of Mathematical Problem Solving Abilities

\begin{tabular}{|c|c|c|c|c|c|c|}
\hline \multirow[t]{2}{*}{ Class } & \multirow[t]{2}{*}{ Test } & \multicolumn{5}{|c|}{$\begin{array}{l}\text { Mathematical Problem Solving } \\
\text { Abilities }\end{array}$} \\
\hline & & $\mathrm{N}$ & Max & Min & Average & $\begin{array}{l}\text { Standard } \\
\text { Deviation }\end{array}$ \\
\hline Eksperiment & \multirow{2}{*}{ Pretest } & 36 & 5 & 1 & 2,36 & 1,27 \\
\hline Control & & 37 & 6 & 0 & 2,35 & 1,42 \\
\hline Eksperiment & \multirow{2}{*}{ Postest } & 36 & 13 & 4 & 8,53 & 2,74 \\
\hline Control & & 37 & 12 & 1 & 6,86 & 2,77 \\
\hline
\end{tabular}

From the table seen at the time of pretest mathematical problem solving ability,in the pretest average of both classes is almost the same that is 2.36 for the experimental class and 2.35 for the control class. However, when the average experimental grade postes 8.53 is much larger than the control class average of 6.86. Descriptively statistically it can be seen that the average increase of experiment class is higher than control class. to verify whether or not the increase will be used the two-averaging difference test for N-Gain. The following will show normality test, homogeneity test and test the difference between two averages for N-Gain data. Normality test results are presented in the following table 2.

Table 2. Test Normality of N-Gain Data Mathematical Problem Solving Ability

\begin{tabular}{lcccl}
\hline & & \multicolumn{3}{c}{ Kolmogorov-Smirnov $^{\mathrm{a}}$} \\
\cline { 3 - 5 } & CLASS & Statistic & Df & Sig. \\
\hline N_Gain_Pemecah Eksperiment & .104 & 36 & $.200^{*}$ \\
an_Masalah & Control & .096 & 37 & $.200^{*}$ \\
\hline
\end{tabular}

Based on the results of output the testof normality usingtest the Kolmogorov-Smirnov in Table 2. the significant value of the data $N$-Gain for the experimental class was 0.200 and 0.200 control class. Both are the same and the significance value of more than 0.05. Based on the decision-making criteria then $\mathrm{H}_{0}$ accepted. This means that samples from the control class and experimental class derived from normal distributed population. After learning that the sample comes from a population that is normally distributed, the next step is to test the homogeneity 
316 Rubaitun, Ruseffendi, \& Syaban Implementasi of Model Eliciting Activities to Improve the Ability of Mathematical Problem Solving

using test Levene with SPSS(Statistical Product and Service Solution) version 16.0 for Windows with a significance level of 0.05 . This is done to see whether the data comes from the same variance or not. After processing the data,display the output can be seen in Table 3 .

Table 3. Test Homogeneity of Two Variances N-Gain

\begin{tabular}{lcccc}
\hline & $\begin{array}{c}\text { Levene } \\
\text { Statistic }\end{array}$ & df1 & df2 & Sig. \\
\hline $\begin{array}{l}\text { N_Gain_Pem Based on } \\
\text { ecahan_Masa Mean } \\
\text { lah }\end{array}$ & .319 & 1 & 71 & .574 \\
\hline
\end{tabular}

Based on the output homogeneity test by using test Levene in table 3. the significance value was 0.574 . Because the significance value of 0.05 , based on the criteria of decision-making can be concluded that there is no difference variance between the experimental class and control class or in other words, the variance between the experimental class and control class is the same. Based on tests of normality and homogeneity tests that have been conducted, data showed normal distribution and homogeneous thus continued to test the difference between two average by using t-test two parties with the help softwareSPSS (Statistical Product and Service Solution) version 16.0 for Windows using independent sample T-Test assuming both homogeneous variance(equalvariance assumed) with a significance level of $0.05 . \mathrm{H}_{0}: \quad \mu_{1}=$ $\mu_{2}$ there was no significant difference between the students' mathematical problem solving ability and the learning using Model-Eliciting Activities with the students who had regular learning, $\mathrm{H}_{1}: \mu_{1}>\mu_{2}$ there is improving students' mathematical problem solving skills whose learning using Model-Eliciting Activities is better than those with regular learning. Decisionmaking criteria, namely:If the significance value less than 0.05 , then $\mathrm{H}_{0}$ is rejected, if the significance value of 0.05 then $\mathrm{H}_{0}$ is accepted. After processing the data, display the output can be seen in Table 4.

Table 4. Test-t of N-Gain Data

\begin{tabular}{|c|c|c|c|c|c|c|c|c|c|}
\hline & \multicolumn{4}{|c|}{$\begin{array}{c}\text { Levene's Test for } \\
\text { Equality of } \\
\text { Variances }\end{array}$} & \multicolumn{5}{|c|}{ t-test for Equality of Means } \\
\hline & \multirow[b]{2}{*}{$\mathrm{F}$} & \multirow[b]{2}{*}{ Sig. } & \multirow[b]{2}{*}{$\mathrm{T}$} & \multirow[b]{2}{*}{ Df } & \multirow{2}{*}{$\begin{array}{l}\text { Sig. } \\
(2- \\
\text { tailed })\end{array}$} & \multirow{2}{*}{$\begin{array}{c}\text { Mean } \\
\text { Differe } \\
\text { nce }\end{array}$} & \multirow{2}{*}{$\begin{array}{l}\text { Std. } \\
\text { Error } \\
\text { Differe } \\
\text { nce }\end{array}$} & \multicolumn{2}{|c|}{$\begin{array}{l}95 \% \text { Confidence } \\
\text { Interval of the } \\
\text { Difference } \\
\end{array}$} \\
\hline & & & & & & & & Lower & Upper \\
\hline $\begin{array}{l}\text { N_Gain_E Equal } \\
\text { Pemecah variances } \\
\text { an_Masa assumed } \\
\text { lah }\end{array}$ & .319 & .574 & $\begin{array}{c}2.5 \\
15\end{array}$ & 71 & .014 & .13023 & .05177 & .02700 & .23345 \\
\hline
\end{tabular}

Sig. (2-tailed) in the Equal variances assumed row in the table is $<0.05$ then $\mathrm{H}_{0}$ is rejected or in other words an increase in problem-solving ability for classes using Model-Eliciting Activities learning is better than the class with regular learning.

\section{CONCLUSION}

Based on the results of processing and data analysis obtained from this study concluded that the improvement of mathematical problem solving ability of MTs students using ModelEliciting Activities is better than using ordinary learning. 


\section{ACKNOWLEDGMENTS}

Place Acknowledgments, including information on the source of any financial support received for the work being published. Place Acknowledgments, including information on the source of any financial support received for the work being published.

\section{REFERENCES}

Chamberlin, S. A., \& Moon, S. M. (2005). Using Model Eliciting Activities as tool to identify and develop Mathematicallly Creative Students. Jornal for the Education of the Gifted, 36(2), 176-197.

Hendriana, H., Rohaeti, E. E., \& Sumarmo, U. (2017). Hard Skills dan Soft Skills Matematik Siswa. BANDUNG: Rafika Aditama.

Martadipura, B. A. P. (2012). Meningkatkan kemampuan berpikir statistis Mahasiswa S1 Pendidikan Matematika Melalui Pembelajaran MEAs yang dimodifikasi. UPI.

Permana, Y. (2010). Mengembangkan Kemampuan Pemahaman, Komunikasi dan Disposisi Matematis Siswa SMA melalui Model Eliciting Activities. UPI.

Russeffendi, H. E. T. (2005). Dasar-dasar Penelitian Pendidikan dan bidang non Eksakta Lainnya. Tarsito.

Widyastuti. (2010). Pengaruh Pembelajaran Model Eliciting Activities terhadap kemampuanrefresentasi matematika dan self-eficacy siswa. Jurnal Pendidikan Matematika Pythagoras, 8(2), 181-192. 